\title{
SISTEM INFORMASI MANAJEMEN PERHITUNGAN BIAYA RAWAT INAP PASIEN DI BALAI PENGOBATAN
}

\author{
Diana Laily Fithri \\ Fakultas Teknik, Progdi Sistem Informasi \\ Universitas Muria Kudus \\ Email: diana.laily@umk.ac.id
}

\begin{abstract}
ABSTRAK
Sistem Informasi Manajemen Perhitungan Biaya Rawat Inap pasien di Balai Pengobatan digunakan untuk mempermudah dalam manajemen Rekam Medis pasien khususnya di dalam hal perhitungan biaya rawat inap pasien yang terdiri dari biaya perawatan, biaya dokter, biaya tindakan, biaya penunjang, dan lain sebagainya. Manajemen perhitungan biaya rawat inap pasien digunakan untuk mempercepat proses dalam antrian pembayaran pasien dan juga untuk mempermudah dalam pencarian data Rekam Medis Pasien. Sehingga proses perhitungan dan pembayaran tidak memerlukan waktu yang lama. Metode Pengembangan yang diguanakan dengan Metode Waterfall dengan hasil penelitian berupa analisa dan perancangan sistem informasi untuk perhitungan biaya rawat inapp pasien pada Balai Pengobatan. Sistem komputerisasi untuk manajemen perhitungan biaya rawat inap pasien juga dapat mempengaruhi kinerja dari pegawai yang ada di Balai Pengobatan. Disamping itu sisi keamanan dan keutuhan data dapat lebih terjamin karena diterapkannya batasan-batasan atas pemakaian data dan hak akses di dalam penggunaan sebuah sistem.
\end{abstract}

Kata kunci: rekam medis, pasien, manajemen.

\begin{abstract}
Cost Calculation Management Information System Inpatient Treatment Center patients are used to simplify the management of patient medical record, especially in terms of the calculation of the cost of hospitalization of patients consisting of treatment costs, doctors' fees, the costs of action, the cost of support, and so forth. The management fee calculation hospitalization of patients used to speed up the payment process in the queue of patients and also to facilitate the search data Patient Medical Record. So that the process of calculation and payment does not require a long time. Method Development diguanakan with Waterfall method with the results of the research is the analysis and design of information systems for the calculation of the cost of care InApp patients at Medical Clinic. The computerized system for the management of patient hospitalization cost calculation can also affect the performance of employees in the Medical Center. Besides, the security and integrity of the data can be more secure because of the application of restrictions on the use of data and accessrights on the use of a system.
\end{abstract}

Keywords: Medical Record, Patient Management.

\section{PENDAHULUAN}

Teknologi informasi berkembang hampir disemua sektor kehidupan manusia. Perkembangan dunia informasi tidak dapat berjalan apabila tidak didukung oleh kemajuan teknologi terutama teknologi komputer. Dengan adanya perkembangan teknologi yang semakin canggih, seolah-olah menuntut suatu lembaga usaha baik negeri maupun swasta untuk dapat mengikuti serta mengetahui arus perkembangan informasi. Dan dengan adanya perkembangan teknologi komputer telah mendorong terjadinya sebuah revolusi teknologi yang membawa ke suatu era yang serba otomatis. Teknologi komputer tersebut memiliki peran yang sangat penting dalam mempengaruhi kinerja sebuah perusahaan, karena pengolahan data diperlukan suatu kecepatan dan ketepatan serta yang tidak kalah pentingnya adalah efisiensi waktu. Balai Pengobatan merupakan suatu lembaga usaha yang bergerak dalam bidang pelayanan jasa kesahatan. Kebutuhan akan pelayanan kesehatan merupakan salah satu kebutuhan yang sangat vital bagi masyarakat. Dalam meningkatkan mutu pelayanan Balai Pengobatan.

Balai Pengobatan merupakan suatu lembaga usaha yang bergerak dalam bidang pelayanan jasa kesahatan. Kebutuhan akan pelayanan kesehatan merupakan salah satu kebutuhan yang sangat vital bagi masyarakat. Dalam meningkatkan mutu pelayanan Balai Pengobatan dengan menurunkan angka 
kematian, kesakitan dan kecacatan serta mengeliminasi ketidakpuasan dan ketidaknyamanan pengguna pelayanan kesehatan Balai Pengobatan. Dalam penanganan masalah yang cepat dan tepat akan menunjang perkembangan perusahaan itu supaya lebih baik.

Menurut Siti Rahma dalam penelitiannya yang berjudul Analisa dan Perancangan sistem rekam medis berbasis LAN di Puskesmas Cilandak menjelaskan bahwa penggunaan komputerisasi pada Puskesmas kecamatan cilandak terutama untuk pengolahan data di bagian tempat pendaftaran pasien rawat jalan, loket pencatatan rekam medis dan tempat pemeriksaan pasien sangat tepat, karena dapat memberikan beberapa keuntungan dan kemudahan dalam pelayanan pasien antara lain, mempercepat pelayanan, informasi lebih akurat dan pencariab data lebih cepat [2]. Dengan adanya program berbasis komputer di tempat pendaftaran, loket pencatatatan rekam medis, dan tempat pemeriksaan pasien maka kinerja suatu puskesma dapat ditingkatkan, sehingga kualitas dan mutu pelayanan menjadi meningkat.

Menurut Made Swasta Adiputra dalam penelitiannya yang berjudul Perancangan sistem informasi Rekam Medis pasien Elektronik terpusat menjelaskan bahwa pengujian desain sistem dilakukan dengan Model Pengujian Object Oriented Analysis and Desain (OOAD) analisis dan desain tidaak dapat diuji dalam artian yang konvensional karena model ini tidak dapat dieksekusi, maka kajian teknis formal dapat digunakan untuk menguji kebenaran dan konsistensi model analisis dan model desain.

\section{METODOLOGI PENELITIAN}

Konsep yang diterapkan dalam tahap perancangan Sistem Informasi perhitungan biaya rawat inap pasien pada Balai Pengobatan Kudus adalah dengan menggunakan Metode Rekayasa Perangkat Lunak Air Terjun (Waterfall) [3]. Tahapan Metode pengembangan sistem dapat dilihat di Gambar 1.

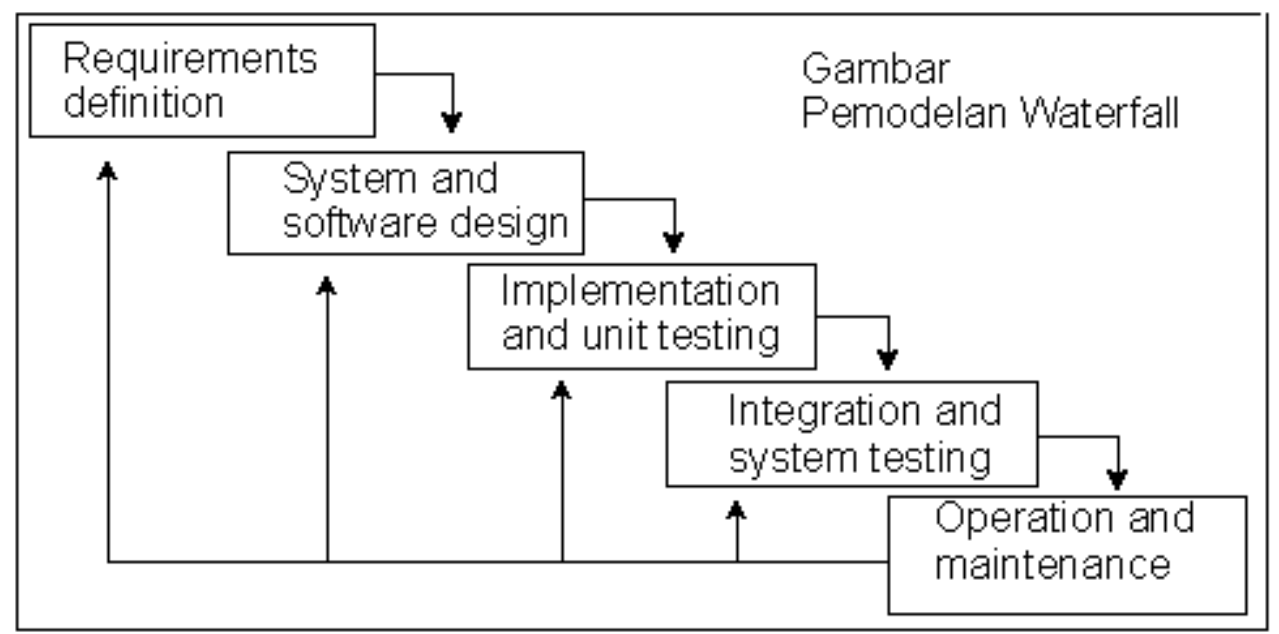

Gambar 1. Tahapan Waterfall [3]

Tahap - tahap dalam model Air Terjun tersebut antara lain :

a. Pendefinisian Masalah dan Analisis Kebutuhan

Pada tahap ini, meliputi penentuan pokok-pokok permasalahan yang terjadi dan kebutuhan dalam perancangan sistem informasi pembayaran pasien rawat inap.

b. Perancangan Sistem dan Perangkat Lunak

Pada tahap ini, meliputi perancangan sistem informasi dan perangkat.

c. Implementasi dan Unit Testing

Pada tahap ini, meliputi penerapan dan pengujian hasil perancangan.

d. Integrasi dan Pengujian Sistem

Pada tahap ini, meliputi penyatuan dan pengujian Sistem secara menyeluruh.

e. Pengoperasian dan Perawatan

Pada tahap ini, meliputi pengoperasian Sistem dan pemeliharaan fakta yang ada di lapangan. 


\section{HASIL DAN PEMBAHASAN}

\subsection{Analisa Use Case Sistem Rekam Medis Pasien}

Use Case diagram sistem Rekam Medis terdiri dari 2 (Dua) actor yaitu Admin dan Kasir. Admin yang mengelola seluruh kegiatan rekam medis pasien mulai dari pendaftaran sampai dengan perhitungan biaya rawat inap pasien. Use Case Diagram dapat dilihat di Gambar 2 yang ada di bawah ini.

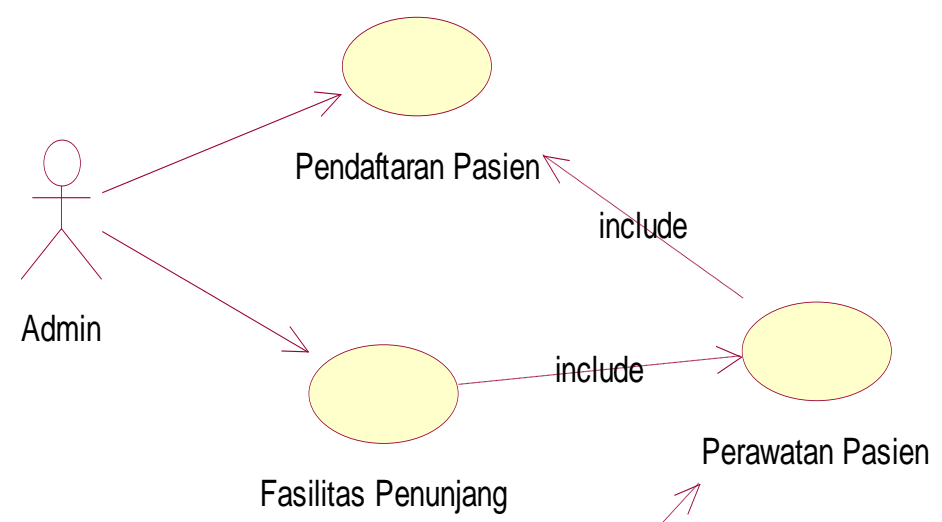

include

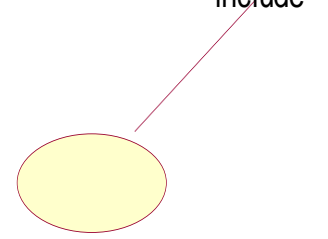

Rekam Medis Pasien

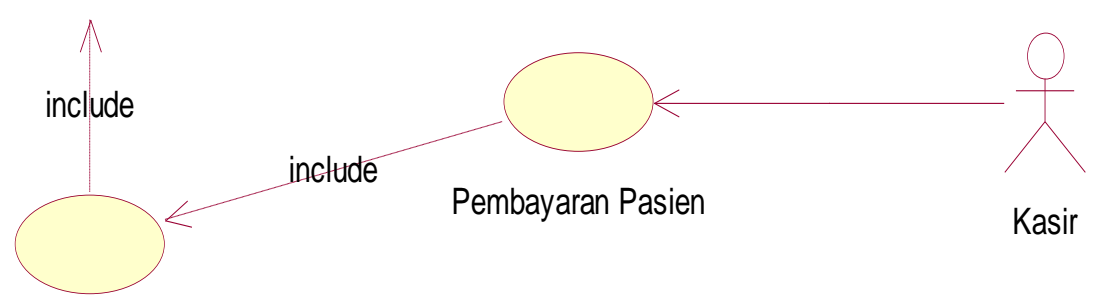

Perhitungan biaya Rawat Inap

Pasien

Gambar 2. Use Case Diagram Rekam Medis Pasien

\subsection{Relasi Tabel Sistem Rekam Medis Pasien}

Di dalam sistem Rekam Medis pasien terdapat tabel pasien, tabel kamar, tabel perawatan, tabel dokter, tabel obat, tabel tindakan, tabel penunjang, dan tabel bayar. Relas table sistem Rekam Medis dapat dilihat di Gambar 3. 


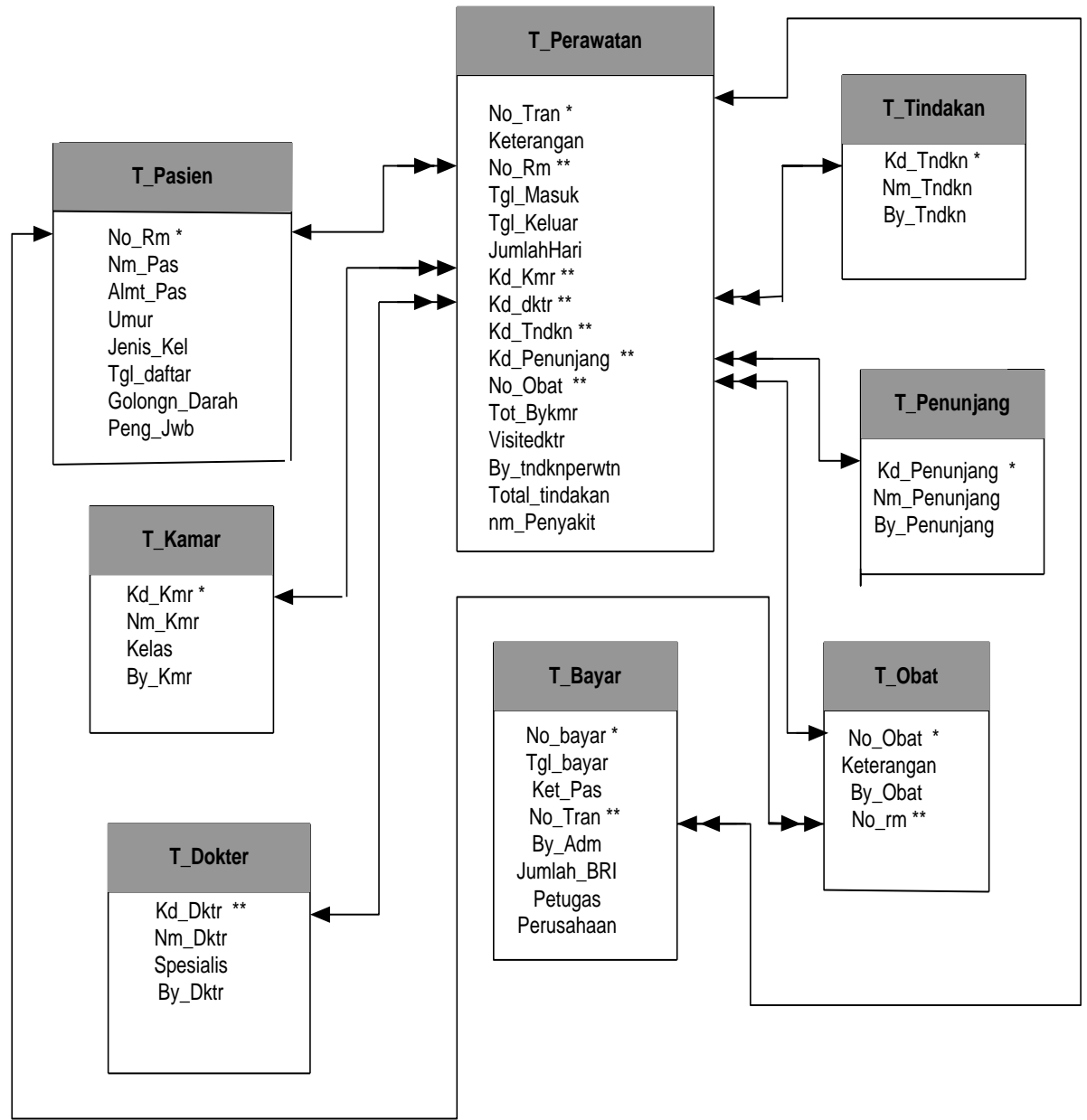

Gambar 3. Relasi Tabel Sistem Rekam Medis

\subsection{Desain Input sistem rekam medis pasien}

Desain Input sistem Rekam Medis Pasien untuk pendaftaran pasien dapat dilihat dalam Gambar 4.

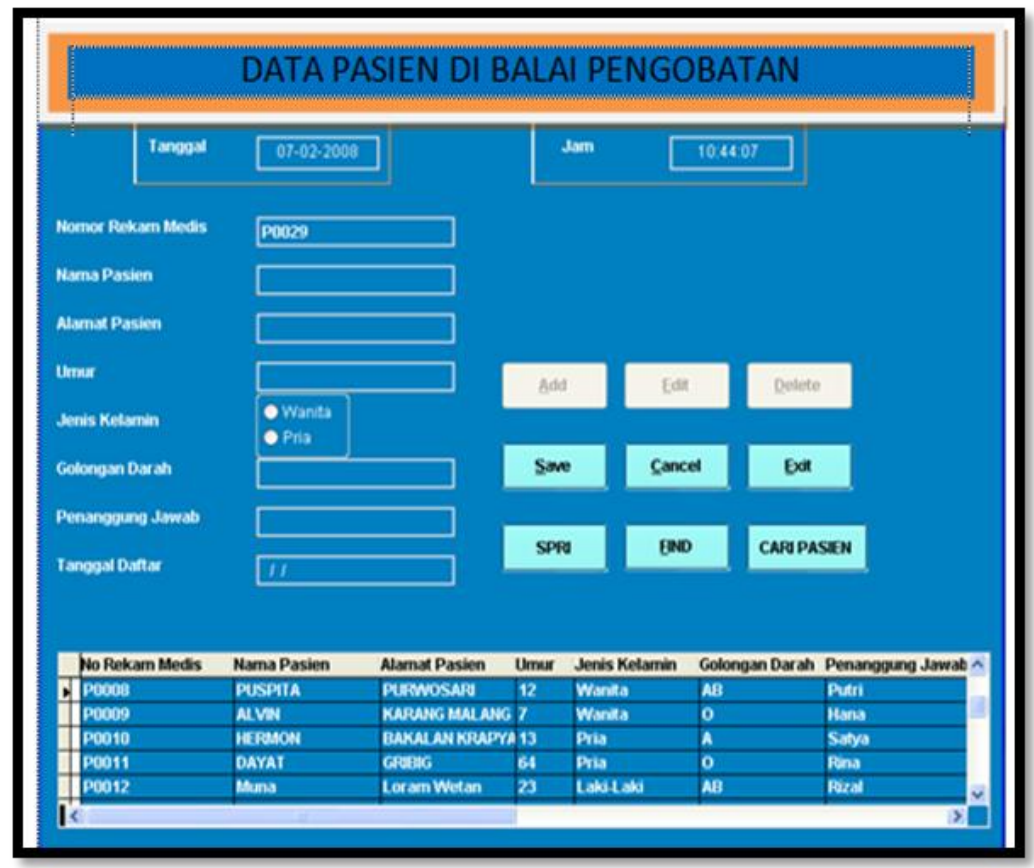

Gambar 4. Pendaftaran pasien di Balai Pengobatan 
Desain Input untuk pemakaian obat pasien dapat dilihat di gambar 5.

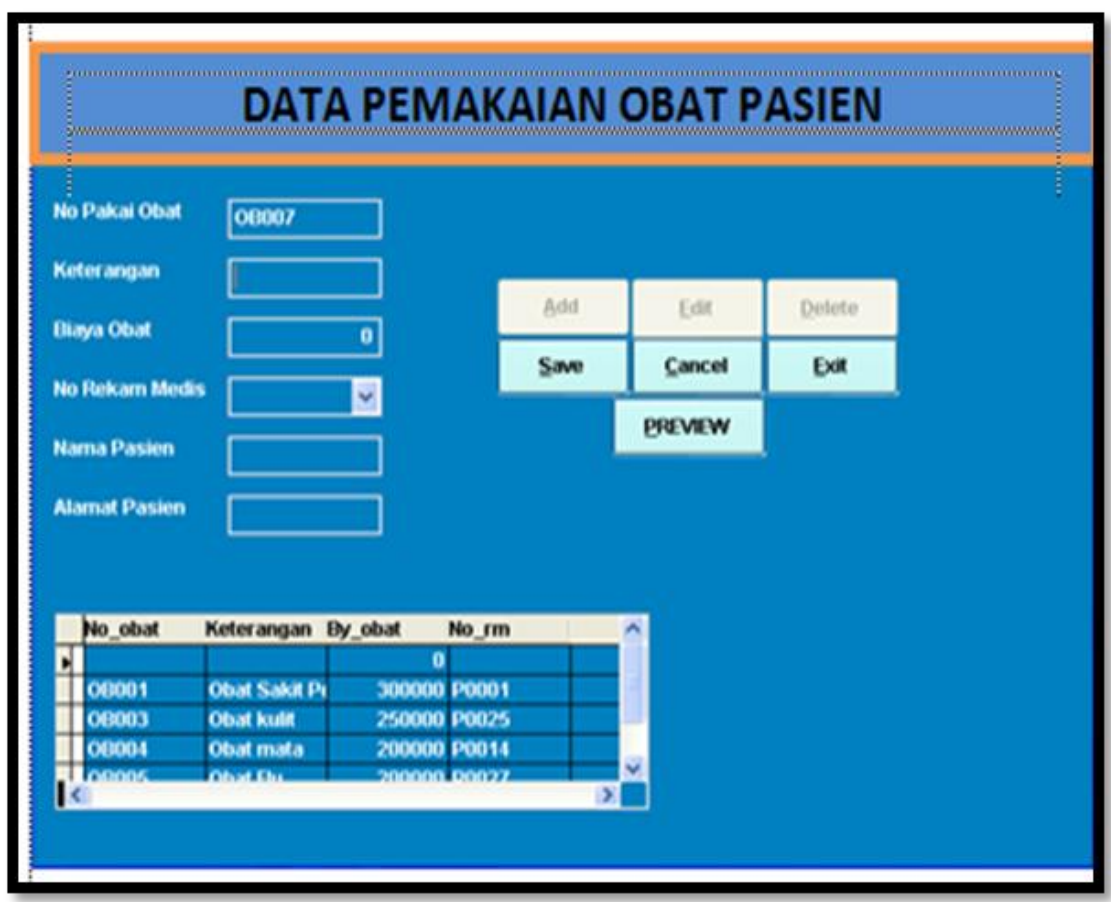

\section{Gambar 5. Pemakaian Obat Pasien}

Desain input untuk Rekam Medis Pasien untuk perawatan Pasien dapat dilihat di gambar 6.

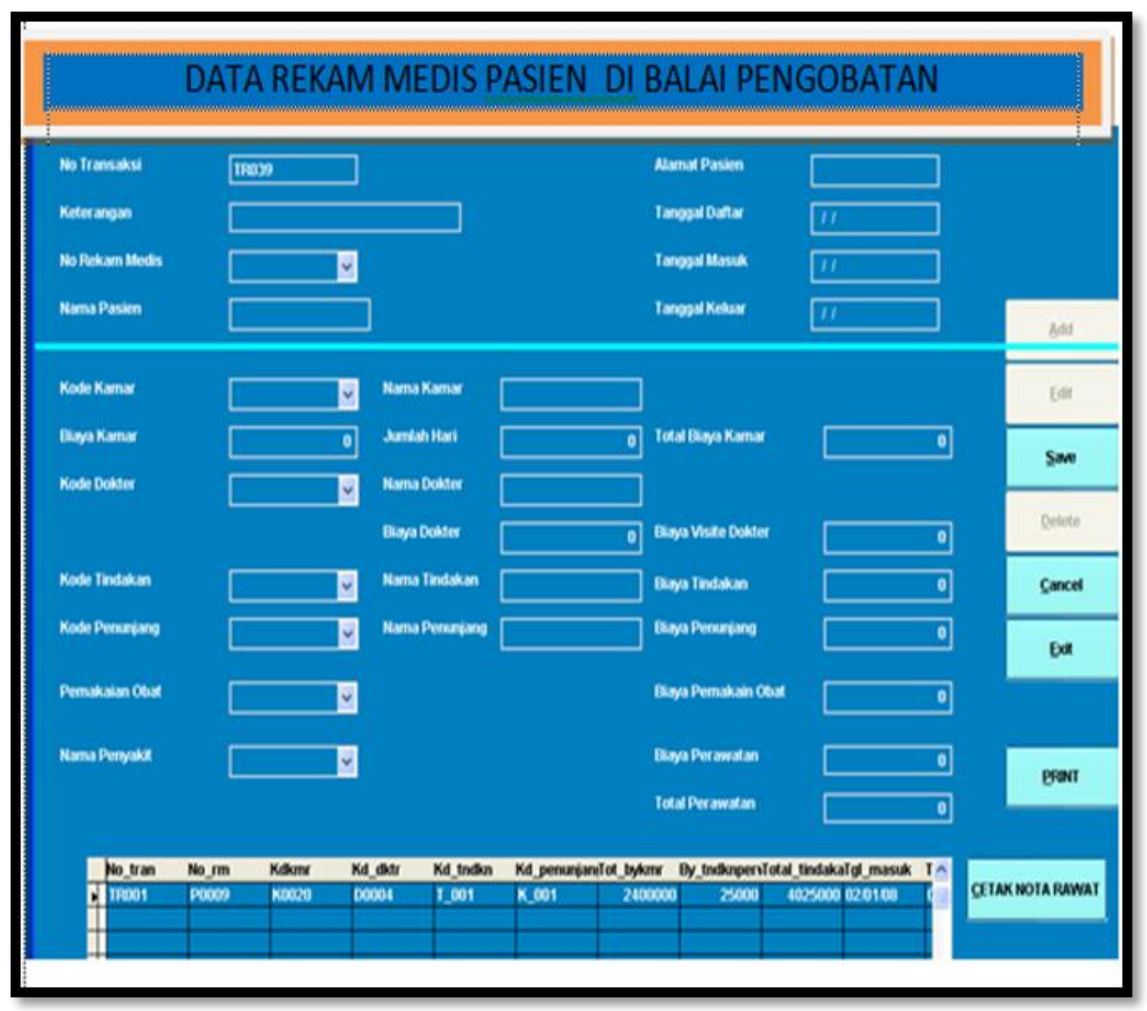

Gambar 6. Data Rekam Medis Pasien

Desain input untuk data perhitungan dan pembayaran Rekam Medis Pasien di Balai Pengobatan dapat dilihat di Gambar 7. 


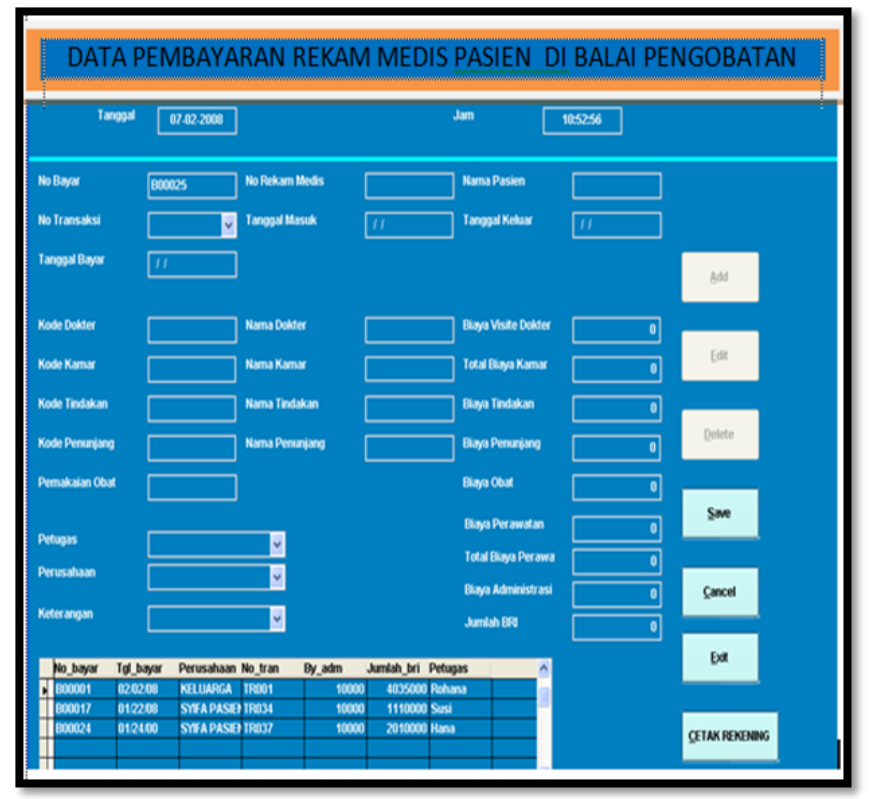

Gambar 7. Data pembayaran Rekam Medis Pasien

Desain input untuk pencarian pasien yang digunakan untuk mempermudah dalam pencarian identitias Rekam medis pasien. Pencarian pasien dapat dilihat di Gambar 8.

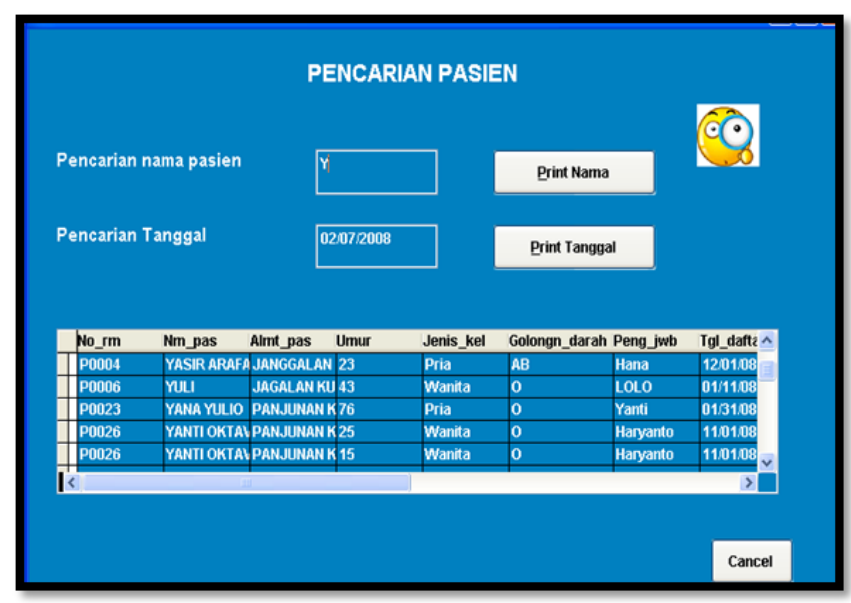

Gambar 8. Desain input untuk pencarian rekam medis pasien

\section{KESIMPULAN}

Sistem ini telah menghasilkan sistem Rekam Medis Pasien dalam hal perhitungan jumlah akhir biaya Rawat Inap yang harus dibayar oleh pasien selama pasien dirawat di Balai Pengobatan, berdasarkan fasilitas yang dipakai diantaranya : jasa kunjungan dokter, ruang perawatan, periksa laborat, pemakaian obat serta tindakan medis dan perawatan lainnya. Disamping itu sistem pembayaran pasien rawat inap ini dapat membuat nota pembayaran yang akan diberikan kepada pasien dan juga laporan transaksi dan pembayaran yang akan diserahkan kepada pihak Balai Pengobatan. Sistem Pembayaran pasien rawat inap ini berguna untuk mengolah data pembayaran pasien rawat inap yang berbasis komputer dengan mudah dan cepat.

\section{DAFTAR PUSTAKA}

[1] Adiputra, I Made Swasta. Perancangan Sistem Informasi Rekam Medis Pasien Elektronik Terpusat. STIMIK AMIKOM Surabaya

[2] Rahma, Siti. 2010. Analisa dan perancangan Sistem Informasi Rekam Medis Pasien rawat Jalan berbasis LAN pada Puskesmas Kecamatan Cilandak. Skripsi

[3] Pressman RS, 2001, "Software Engineering : a practitioners approach", Mc Graw Hill Companies, Inc.

[4] Suhendar. 2002. Visual Modeling Menggunakan UML dan Rational Rose. Informatika: Bandung 